\title{
Deficiencies in anti-acetylcholine receptor antibody measurement in myasthenia gravis
}

\author{
C E Clarke, D I Shepherd, G M Yuill, J C Smaje, P B Wilson
}

\begin{abstract}
In a retrospective case note study of 86 patients with myasthenia gravis, 60 had an anti-acetylcholine receptor antibody assay performed by the regional immunology laboratory. Antibody was detected in $38 \%$ which compares with $66-93 \%$ in other series. Whilst the use of staphylococcal protein $A$ to precipitate the antibody-receptor complex, rather than anti-human immunoglobulin, may be partly responsible for this low sensitivity, other methodological problems are likely to exist. It is suggested that this potentially critical assay becomes a subject for regular audit.
\end{abstract}

The investigation and management of myasthenia gravis (MG) has changed dramatically in the 50 years since Mary Walker first described the response to cholinesterase preparations. ${ }^{1}$ The combination of sensitive radioimmunoassays for anti-acetylcholine receptor (AChR) antibodies ${ }^{23}$ and sophisticated electrophysiological techniques ${ }^{4}$ has allowed the diagnosis to be made at a much earlier stage in the evolution of the disease. The move away from high dose anticholinesterase therapy to thymectomy and immunosuppression has further improved the outlook for myasthenic patients, ${ }^{5}$ as have improvements in intensive care facilities and the use of plasmapheresis in the acute phase. ${ }^{6}$

We have recently examined the effects of these developments on the management of MG over a nine year period in a sub-regional neurology centre which serves a population of approaching one million. Significant deficiencies were found in the sensitivity of the AChR antibody assay in our region. The potential causes for this are discussed, as well as the need for similar audit studies in other regions.

\section{Patients and methods}

The study is based on the 86 patients with "clinically definite" MG seen by two of us (DIS and GMY) over the nine year period from the start of a diagnostic index to 1 August 1988. "Clinically definite" cases were defined as patients with fatiguable weakness of extraocular, bulbar or limb muscles which was felt to be diagnostic of myasthenia by a consultant neurologist. All cases of the
Lambert-Eaton myasthenic syndrome and congenital myasthenia were excluded. Information concerning the clinical presentation, the results of investigations and the outcome of therapy was gained from the patients case notes. Patients were divided into four groups according to the worst clinical grade of myasthenia they had suffered by 1 August 1988 using the classification of Osserman ${ }^{7}$ : Iocular, II-generalised, III-acute fulminating and IV-late fulminating (after initial presentation in category I or II).

The "Tensilon" test was performed in the standard manner with initially $1 \mathrm{mg}$ of intravenous edrophonium followed by a further $9 \mathrm{mg}$ in two fractions in the absence of any reduction in muscle weakness. Most patients were premedicated with $0.6 \mathrm{mg}$ of atropine by the intramuscular route. Repetitive stimulation studies were performed on trapezius, deltoid or abductor digiti minimi or two of these muscles with stimulation rates of $2,5,10,20$ and $50 \mathrm{~Hz}$. A positive result was signified by a decrement in the compound muscle action potential amplitude of the fifth potential compared with the first of greater than $10 \%$ either before or after 30 seconds exercise. Single fibre electromyography (SFEMG) was performed in the extensor digitorum communis and was considered abnormal if blocking was present in any of 20 potential pairs, if jitter was greater than $55 \mu \mathrm{s}$ in more than one pair or if the mean jitter of 20 pairs exceeded $33 \mu \mathrm{s}$.

The anti-acetylcholine receptor antibody assay was performed in the regional immunology laboratory (PBW) using a method modified from that described by Brenner et al. ${ }^{8}$ Acetylcholine receptors were isolated from human calf muscle obtained from amputations. Homogenised muscle was extracted with Triton X-100 and the preparation ultracentrifuged. The resulting supernatant was aspirated and stored at $4^{\circ} \mathrm{C}$ with $0 \cdot 1 \%$ azide added as a preservative. Alpha-bungarotoxin (10 $\mu \mathrm{g}$, Sigma T3019) was radio-labelled with $25 \mathrm{mBq}{ }^{125} \mathrm{I}$ (Amersham) and the resulting preparation separated from free iodine by addition of a cationic ion exchange resin (Amberlite IRA 400). Two hundred and fifty microlitres of the receptor preparation was labelled by the didition of 25 al whabungarotoxin equivalent to $25-50000 \mathrm{cpm}$. One hundred microlitres of patient's diluted 
(1:10) serum were added to the receptor-bungarotoxin complex and incubated overnight at room temperature. The resulting complexes were separated from the free label by addition of a suspension of 1-2 mg of staphylococcal dried cells (Sigma SO504). After two hours, the tubes were centrifuged and washed twice to remove unbound radio-labelled receptor. The lower limit of detection for the assay was determined by measuring the radioactive counts bound in normal individuals, from which the upper limit of the normal range was calculated by taking the mean plus three standard deviations. AChR antibody levels obtained at the time of diagnosis were used throughout the study to exclude the effects of treatment on antibody production.

\section{Results}

Of a total of 86 patients, only 60 were examined for the presence of the anti-acetylcholine receptor antibody. These comprised 18 cases $(30 \%)$ of pure ocular myasthenia (type I), 38 cases $(63 \%)$ with generalised disease (type II), $3(5 \%)$ with acute fulminating disease (type III) and $1(2 \%)$ with late fulminating disease (type IV).

Patients were included in the series on clinical criteria alone. However, support for the diagnosis of myasthenia was gained from investigations in a large proportion of patients (table 1). One or more investigations corroborated a diagnosis of myasthenia in $50 \%$ of patients with type I disease and $95 \%$ of those with types II-IV disease.

Antibody directed at the $\mathrm{AChR}$ was detected in $23(38 \%)$ of the 60 patients examined. In cases of ocular myasthenia, only two $(11 \%)$ of the 18 tested were positive, whereas in patients with generalised disease (types II-IV), 21 $(50 \%)$ of 42 were positive. Of the nine cases of ocular myasthenia with no positive additional tests, five had a negative Tensilon test; all of these had a negative AChR test.

No trend was found in anti-AChR antibody titre in relation to disease classification (table 2; ANOVA $F_{3,27}=1 \cdot 89, p>0.05$ ).

\begin{abstract}
Discussion
As a retrospective case note study, this work is limited by the lack of comprehensive investigation in some cases. There was also a high percentage of cases of ocular myasthenia (31\% across the group of $\mathbf{8 6}$ patients) compared with other series with a frequency of between 9-29\%. ${ }^{7-11}$ Similarly, only $6 \%$ had fulminating disease (types III and IV) compared with
\end{abstract}

Table 1 Corroborating investigations in study patients

\begin{tabular}{|c|c|c|c|c|c|c|}
\hline \multirow[b]{3}{*}{ Investigation } & \multicolumn{6}{|l|}{ Result } \\
\hline & \multicolumn{3}{|c|}{ Ocular (type I) } & \multicolumn{3}{|c|}{ Generalised (types II-IV) } \\
\hline & Abnormal & Normal & $N D^{\star}$ & Abnormal & Normal & $N D$ \\
\hline $\begin{array}{l}\text { Terisilon test } \\
\text { Repetitive otimulation } \\
\text { SFEMG: }\end{array}$ & $\begin{array}{l}8(62 \%) t \\
1(9 \%) \\
1(14 \%)\end{array}$ & $\begin{array}{r}5 \\
10 \\
6\end{array}$ & $\begin{array}{c}5 \\
71 \\
11\end{array}$ & $\begin{array}{l}37(88 \%) \dagger \\
17(57 \%) \\
9(82 \%)\end{array}$ & $\begin{array}{r}5 \\
13 \\
2\end{array}$ & $\begin{array}{l}0 \\
12 \\
31\end{array}$ \\
\hline
\end{tabular}

\#ND represents patients in which this investigation was not performed.

† Number of abnormal tests as a percentage of all in which test was carried out.
Table 2 Anti-acetylcholine receptor antibody titres

\begin{tabular}{rlllll}
\hline & & \multicolumn{4}{c}{ Disease classification } \\
\cline { 3 - 6 } Titre $^{\star}$ & $\begin{array}{l}\text { Number of } \\
\text { patients }\end{array}$ & I & II & III & IV \\
\hline 0 & 17 & 10 & 7 & 0 & 0 \\
1 & 8 & 3 & 5 & 0 & 0 \\
2 & 9 & 3 & 6 & 0 & 0 \\
3 & 2 & 0 & 2 & 0 & 0 \\
$4-9$ & 1 & 0 & 1 & 0 & 0 \\
$10-19$ & 5 & 1 & 4 & 0 & 0 \\
$20-29$ & 2 & 0 & 0 & 2 & 0 \\
$30-39$ & 2 & 0 & 1 & 0 & 1 \\
$40-49$ & 1 & 1 & 0 & 0 & 0 \\
$50-59$ & 2 & 0 & 2 & 0 & 0 \\
$60-69$ & 3 & 0 & 2 & 1 & 0 \\
$70-79$ & 2 & 0 & 2 & 0 & 0 \\
$80-89$ & 0 & 0 & 0 & 0 & 0 \\
$90-99$ & 1 & 0 & 1 & 0 & 0 \\
$100-199$ & 2 & 0 & 2 & 0 & 0 \\
$200-299$ & 1 & 0 & 1 & 0 & 0 \\
\hline
\end{tabular}

^Expressed in arbitrary units; a titre of four or more is considered abnormal compared with normal population. $\dagger$ The titres of two patients were not available, one was positive and the other negative.

the $22 \%^{7}$ and $35 \%^{11}$ recorded by others, although the declared interest of the latter groups in myasthenia may have encouraged the referral of more difficult cases.

Nevertheless, the comparatively low detection rate of the anti-AChR antibody assay is surprising. Positive results were obtained in $38 \%$ of cases of clinically definite $\mathrm{MG}$ in contrast to a range of $66-93 \%$ reported by other groups where anti-human immunoglobulin rather than protein A was used for the separation step. ${ }^{2311-13}$ The incidence of presumed false negatives was most marked in those with ocular myasthenia, where only $11 \%$ of sera tested were positive, compared with $50 \%{ }^{13}$ and $55 \%^{12}$ in other studies. The detection rate in patients with generalised myasthenia was higher $(50 \%)$, but remains low compared with other reports of $88 \%^{12}$ and $92 \%^{13}$ in equivalent groups.

It is conceivable that the five patients with supposed ocular myasthenia who had both negative Tensilon tests and anti-AChR antibody assays did not have myasthenia gravis in spite of the finding of fatiguable ptosis or ophthalmoplegia. The apparent sensitivity of the assay would increase if these cases were omitted from the audit. However, investigative support for the diagnosis in those with generalised disease (types II-IV) was found in $95 \%$ and yet the sensitivity of the AChR antibody assay was still below that found by others.

There is undoubtedly a group of myasthenic patients with antibodies directed at the AChR that cannot be detected. If immunoglobulin from such patients is administered to mice, a defect of neuromuscular transmission develops, presumably due to the presence of antibodies directed at antigenic determinants on areas of the AChR other than the main immunogenic region or even other proteins at the neuromuscular junction. ${ }^{14}$ The disparity, however, between our results and those of other workers suggests there is a problem inherent within the methodology of the immuno-assay curready employed. The protocol used in our revional immunology laboratory was originally described by Brenner et $a l^{8}$ and utilises staphylococcal protein A to 
precipitate the AChR-antibody complex and thus differs from other *nethods which use the more expensive anti-human IgG antisera. This group found that only $37 \%$ of their myasthenic patients showed significantly increased AChR binding which compares closely with our figure of $38 \%$. It has been suggested that since staphylococcal protein A only binds to IgG subclasses 1,2 and 4, with minimal binding to IgG3, that a number of myasthenic patients with anti-AChR antibody of predominantly IgG3 class may not be detected by this type of assay. ${ }^{15}$ Proponents of this view have found that more than $50 \%$ of the anti-AChR antibody was of the IgG3 class in over $50 \%$ of their patients. ${ }^{15-17}$ In analogous experiments Vincent and Newsom-Davis ${ }^{18}$ have found the proportion of IgG3 to be in the region of $10 \%$ only in generalised myasthenia and $23 \%$ in ocular disease. Tindall ${ }^{12}$ also found a strict correlation between the number of patients with significantly raised anti-AChR antibodies using the staphylococcal protein $\mathrm{A}$ and anti-human immunoglobulin techniques, although antibody titres were $6.5 \%$ higher using the latter method.

The use of staphylococcal protein A rather than anti-human IgG antisera may account in part for the low sensitivity of our assay, but it is probable that other methodological reasons are involved. One possibility relates to the receptor preparation which in these studies was isolated from single individuals rather than using preparations of pooled material. Samples from this same group of patients are currently being re-analysed taking these factors into account.

The findings of this study emphasise the value of medical audit, even when applied to apparently well established practices. Similar studies into the sensitivity of the anti-AChR antibody assay should be performed in other centres and, if comparable results are found, consideration should be given to creating a central reference laboratory for this assay.
We thank Miss H Botteley and Miss K Adamson for obtaining patient records.

Walker MB. Treatment of myasthenia gravis with physostigmine. Lancet 1934;i:1200-1.

2 Lindstrom JM, Seybold ME, Lennon VA, Whittingham S, Duane DD. Antibody to acetylcholine receptor in myasthenia gravis. Neurology 1976;26:1054-9.

3 Vincent A, Newsom-Davis J. Acetylcholine receptor antibody as a diagnostic test for myasthenia gravis: Results in 153 validated cases and 2967 diagnostic assays. $J$ Neurol Neurosurg Psychiatry 1985;48:1246-52.

4 Stålberg DEL. Clinical electrophysiology in myasthenia gravis. J Neurol Neurosurg Psychiatry 1980;43:622-33.

5 Engel AG. Myasthenia gravis and myasthenic syndromes. Ann Neurol 1984;16:519-34.

6 Pinching AJ, Peters DK, Newsom-Davis J. Remission of myasthenia gravis following plasma exchange. Lancet 1976;ii: $1373-6$.

7 Osserman KE. Myasthenia gravis. London: Grune and Stratton, 1958.

8 Brenner T, Zweiman B, Abramsky O, Tarrab-Hazdai R, Lisak RP, Fuchs S. Radioimmunoassay of antibodies to acetylcholine receptor in serum of myasthenia gravis acetylcholine receptor in serum of my
patients. Israel J Med Sci 1978;14:986-9.

9 Perlo VP, Poskanzer DC, Schwab RS, Viets HR, Osserman KE, Genkins G. Myasthenia gravis: Evaluation of treatment in 1355 patients. Neurology 1966;16:431-9.

10 Grob D, Brunner NG, Namba T. The natural course of myasthenia gravis and effect of therapeutic measures. Ann NY Acad Sci 1981;377:652-69.

11 Compston DAS, Vincent A, Newsom-Davis J, Batchelor JR. Clinical, pathological, HLA antigen and immunological evidence for disease heterogeneity in myasthenia gravis. Brain 1980;103:579-601.

12 Tindall RSA. Humoral immunity in myasthenia gravis. Biochemical characterisation of acquired antireceptor antibodies and clinical correlations. Ann Neurol 1981; 10:437-47.

13 Limburg PC, The TH, Hummel-Tappel E, Oosterhuis HJGH. Anti-acetylcholine receptor antibodies in myasthenia gravis. J Neurol Sci 1983;58:357-70.

14 Mossman S, Vincent A, Newsom-Davis J. Myasthenia gravis without acetylcholine receptor antibody: A distinct disease entity. Lancet 1986;i:116-9.

15 Fulpius BW, Lefvert AK, Cuenoud S, Mourey A. Properties and serum levels of specific populations of anti-acetylcholine receptor antibodies in myasthenia gravis. $A n n N Y$ Acad Sci 1981;377:307-15.

16 Lefvert AK, Bergstrom K. Acetylcholine receptor antibody in myasthenia gravis. Purification and characterization. Scand J Immunol 1978;8:525-33.

17 Lefvert AK. The human acetylcholine receptor antibody: Studies of kinetic and biochemical properties and the reaction with anti-idiotypic antibodies. Ann NY Acad Sci 1981;377:125-42.

18 Vincent A, Newsom-Davis J. Acetylcholine receptor antibody characteristics in myasthenia gravis. I. Patients with generalised myasthenia or disease restricted to ocular muscles. Clin Exp Immunol 1982;49:257-65. 